\title{
PENGARUH PROFITABILITAS, LEVERAGE, DAN UKURAN PERUSAHAAN TERHADAP PENGUNGKAPAN CORPORATE SOCIAL RESPONSIBILITY (CSR)
}

\author{
Heddy Arif Rachman dan Anita Nopiyanti \\ arifheddy@rocketmail.com,atina.itnayipon@gmail.com \\ Fakultas Ekonomi UPN "Veteran” Jakarta \\ Jl. R.S. Fatmawati Pondok Labu, Jakarta Selatan - 12450
}

\begin{abstract}
The purpose of this study was to examine the influence of probability, leverage, and company size to corporate social responsibility disclousure. The independent variables in this study is probability, leverage, and company size. The dependent variable in this study is the corporate social responsibility disclousure, with years of research for 2010-2013. The sample in this study is mining companies that go public in Indonesia Stock Exchange (BEI) and have reported the corporate social responsibility disclosure activities. There are 36 samples by purposive sampling method. This study uses multiple linear regression analysis. The results showed that there was no significant relationship between profitability and leverage on the disclosure of corporate social responsibility. Instead, there is a significant influence in the presence of company size on disclosure of corporate social responsibility.
\end{abstract}

Keyword: probability, leverage, company size, corporate social responsibility disclousure

\section{PENDAHULUAN}

Perusahaan merupakan bagian dari masyarakat dan lingkungan, keberadaannya tidak terlepas dari masyarakat dan lingkungan. Selama ini banyak perusahaan berusaha untuk mencapai laba maksimum dan meminimumkan pengorbanan yang dilandasi oleh kepentigan pribadi. Sebagai akibatnya banyak terjadi berbagai skandal keuangan maupun lingkungan yang merugikan dunia bisnis dan masyarakat.

Tanggung jawab sosial perusahaan atau juga dikenal dengan corporate social responsibility (CSR) merupakan sebuah gagasan yang menjadikan perusahaan tidak lagi dihadapkan pada tanggung jawab yang berpijak pada single bottom line, yaitu nilai perusahaan (corporate value) yang di refleksikan dalam kondisi keuangan (financial) saja. Tetapi tangung jawab perusahaan harus berpijak pada triple bottom lines yaitu juga memperhatikan masalah sosial dan lingkungan (Daniri, 2008 dalam Badjuri, 2011).

Penerapan Corporate Social Responsibility (CSR) oleh perusahaan dapat di wujudkan dengan pengungkapan Corporate Social 
Resonsibility (CSR) yang disosialisasikan ke publik dalam laporan tahunan (annual report) perusahaan (Sari, 2012). Sesuai dengan Undang-Undang No. 40 Tahun 2007 tentang Perseroan Terbatas yang mewajibkan Perseroan yang bidang usahanya dibidang atau terkait dengan bidang sumber daya alam untuk melaksanakan tanggung jawab sosial dan likungan. Pengungkapan CSR juga telah di atur dalam Pernyataan Standart Akuntansi Keuangan (PSAK) No. 1 paragraf 9 tentang pengungkapan dampak lingkungan.

Fenomena yang terjadi pada penelitian ini ialah PT. Freeport Indonesia dengan masyarakat suku di Papua. Aktivitas pertambangan PT Freeport McMoran Indonesia (Freeport) di Papua, dimulai sejak tahun 1967 hingga saat ini, berlangsung selama 44 tahun. Selama ini, kegiatan bisnis dan ekonomi Freeport di Papua, telah mencetak keuntungan financial yang sangat besar bagi perusahaan asing tersebut. Ketua DPN Repdem, Masinton Pasaribu menjelaskan, penghasilan bersih PT Freeport Indonesia, perharinya mencapai US\$20 juta atau jika dikalikan dengan 31 hari hasilnya adalah: US\$ 620 Juta (jika dirupiahkan sekitar 5,5 triliun). Apabila penghasilan PT Freeport Indonesia sebesar US\$589 juta per bulan, maka penghasilan bersih Freeport pertahunnya kurang lebih 70 triliun rupiah, kalau dikalikan dengan 44 tahun keberadaan Freeport di Indonesia maka keuntungan bersihnya mencapai 3.000 triliun. Namun pada kenyataanya besarnya hasil yang diperoleh PT Freeport Indonesia tidak sebanding dengan besarnya kesejahteraan yang diberikan PT Freeport kepada karyawan dan masyarakat Papua selain meminta peningkatan kesejahteraan, para pekerja juga meminta kepada perusahaan meningkatkan pelayanan kesehatan, pendidikan, dan transportasi.

PT Freeport Indonesia dengan memperoleh keuntungan sebesar 70 triliun rupiah setiap tahunnya, melakukan pengungkapan corporate social responsibility lebih luas. Tetapi faktanya PT Freeport Indonesia masih melakukan pelanggaran terhadap masyarakat papua seperti pelanggaran HAM, serta pelanggara mengenai ketenaga kerjaan. Seharus PT Freeport Indonesia merupakakn perusahaan yang besar dengan laba yang tinggi yaitu sebesar 70 triliun pertahunnya melakukan pengungkapan corporate social responsibility secara luas dan transparan.

Penelitian ini merujuk pada penelitian Nur \& Priantinah (2012) dan Sari (2012). Perbedaan penelitian terdahulu dengan penelitian ini adalah pada penelitian Nur \& Priantinah (2012) menggunakan variabel independen kepemilikan saham publik, profitabilitas, pengungkapan media, ukuran perusahaan, dewan komisaris, dan leverage. Penelitian Sari (2012) menggunakan variabel independen tipe industri, ukuran perusahaan, profitabilitas, leverage, dan pertumbuhan perusahaan. Sedangkan dalam penelitian ini menggunakan variabel profitabilits, leverage, dan ukuran perusahaan terhadap pengungkapan corporate social responsibility (CSR). Perbedaan 
selanjutnya yaitu sampel yang digunakan dan juga periode tahun dalam penelitian ini lebih baru yaitu tahun 2011-2013.

Tujuan penelitian ini adalah untuk menganalisis pengaruh profitabilitas, leverage, dan ukuran perusahaan terhadap pengungkapan CSR pada perusahaan sektor pertambangan yang terdaftar di BEI selama periode 2011-2013. Hasil penelitian ini diharapkan dapat dijadikan bahan pertimbangan bagi investor dalam berinvestasi dan sebagai bahan pertimbangan bagi perusahaan dalam mengaplikasikan variabel-variabel penelitian ini untuk membantu memperluas pengungkapan CSR.

\section{TINJAUAN PUSTAKA DAN HIPOTESIS}

Teori Legitimasi

Legitimasi

merupakan faktor yang sangat strategis bagi perusahaan sebagai salah satu cara untuk mengembangkan perusahaan kedepan. Hal itu dapat dijadikan sebagai alat untuk merancang strategi perusahaan, terutama terkait dengan upaya memposisikan diri ditengah lingkungan masyarakat yang semakin maju.

Legitimasi itu sendiri adalah keadaan psikologis keberpihakan orang dan kelompok orang yang sangat peka terhadapat gejala lingkungan sekitarnya baik dalam bentuk fisik maupun nonfisik. O'Donova (2002) dalam Hadi (2014, hlm.87) menyatakan pendapat bahwa legitimasi organisasi dapat dilihat sebagai sesuatu yang diberikan masyarakat kepada peusahaan dan sesuatu yang diinginkan atau dicari perusahaan dari masyarakat.Dengan demikian, legitimasi merupakan manfaat atau sumber daya potensial bagi perusahaan untuk bertahan hidup (going concern).

\section{Teori Agensi (Agency Theory)}

Dalam

agency theory

menyebutkan bahwa perusahaan adalah tempat atau interectin point bagi hubungan kontrak yang terjadi antara manajemen, pemilik, kreditor dan pemerintah. Salah satu hipotesis dalam teori agency ini adalah bahwa manajemen akan mencoba memaksimalkan kesejahteraan sendiri dengan cara meminimalisasi berbagai biaya agency (agency theory) (Harahap, 2011, hlm.532). Teori keagenan menunjukkan bahwa kondisi informasi yang tidak lengkap dan penuh ketidakpastian akan memunculkan masalah keagenan. Dalam kondisi yang demikian pemilik perlu menunjuk pihak lain (agen) yang profesional, untuk melaksanakan tugas mengelola kegiatan perusahaan dengan lebih baik.

\section{Pengungkapan Corporate Social Responsibility (CSR)}

Pengungkapan corporate social responsibility merupakan proses pengkomunikasian dampak sosial dan lingkungan dari kegiatan ekonomi organisasi terhadap kelompok khusus yang berkepentingan dan terhadap masyarakat secara keseluruhan' (Sembiring, 2005).

Pengungkapan corporate social responsibility diukur dengan proksi corporate social responsibility index 
berdasarkan Global Reporting Initiative (GRI) dengan jumlah 79 item pengungkapan yang meliputi 6 katagori yaitu economic (EC), environment (EN), human rights (HR), labor practices (LP), product responsibility (PR), dan society (SO)

\section{Profitabilitas}

Tujuan akhir yang ingin dicapai suatu perusahaan yang terpenting adalah untuk memperoleh laba yang maksimal,perusahaan dapat berbuat banyak bagi kesejahteraan pemilik, karyawan, serta meningkatkan mutu produk dan melakukan investasi baru. Oleh karena itu, manajemen perusahaan dalam pratiknya dituntut harus mampu untuk memenuhi target yang telah ditetapkan, dimana besarnya laba atau keuntungan haruslah dicapai sesuai dengan yang diharapkan.

Hubungan kinerja keuangan dengan tanggung jawab sosial perusahaan paling baik diekspresikan dengan profitabilitas, hal ini karena pandangan bahwa tanggapan sosial yang diminta dari manajemen sama dengan kemampuan yang diminta untuk membuat suatu perusahaan memperoleh laba. Semakin tinggi tingkat profitablitas suatu perusahaan maka semakin luas corporate social responsibility disclosure, perolehan laba yang semakin besar akan membuat perusahaan mengngkapkan informasi sosial yang lebih luas (Sari, 2012).

\section{Leverage}

Untuk menjalankan operasinya setiap perusahaan memiliki berbagai kebutuhan, terutama yang berkaitan dengan dana agar peruasahaan dapat berjalan dengan mestinya. Dana selalu dibutuhkan untuk menutupi seluruh atau sebagian dari biaya yang diperlukan, baik dana jangka pendek maupun jangka panjang. Dalam memenuhi kebutuhan dananya, perusahaan menggunakan modal sendiri dan juga pinjaman atau hutang.

Leverage mencerminkan resiko keuangan perusahaan karena dapat menggambarkan srtuktur modal perusahaan dan mengetahui resiko tak tertagihnya suatu utang, Semakin tinggi leverage suatu perusahaan, maka perusahan memiliki resiko keuangan yang tinggi sehingga menjadi sorotan dari debtholders. Perusahaan dengan tingkat leverage yang tinggi cenderung ingin melaporkan laba lebih tinggi agar dapat mengurangi kemungkinan perusahaan melanggar perjajian utang (Sari, 2012).

\section{Ukuran Perusahaan}

Ukuran perusahaan merupakan salah satu variabel yang umum digunakan untuk menjelaskan mengenai variasi pengungkapan dalam laporan tuhunan perusahaan. Berkembang suatu fenomena bahwa pengaruh total aktiva (proksi dari ukuran perusahaan) hampir selalu kosisten dan secara signifikan berpengaruh terhadap kualitas pengungkapan. Ukuran perusahaan juga merupakan variabel yang penting dalam praktik CSR. Dalam penelitian ini, ukuran perusahaan diukur dengan menggunakan logaritma natural dari total aktiva.(Purwanto, 2011).

Perusahaan besar tidak akan lepas dari tekanan, semakin besar 
suatu perusahaan dengan aktivitas opersional, pengaruh yang lebih besar terhadap masyarakat dan memiliki pemegang saham yang memperhatikan program sosial yang dibuat oleh perusahaan sehingga pengungkapan corporate social responsibilityakan semakin luas (Sembiring, 2005).

\section{Pengaruh Profitabilitas terhadap Pengungkapan Corporate Social Responsibility (CSR)}

Profitabilitas menggambarkan kemampuan perusahaan mendapatkan laba melalui semua kemampuan, dan sumber yang ada seperti kegiatan penjualan, kas, modal, jumlah cabang, dan sebagainya. Rasio yang menggambarkan kemampuan perusahaan menghasilkan laba disebut juga operating ratio (Harahap, 2011, hlm.304). Dalam berkaitan profitabilitas Amran dan Devi (2008) dalam Eka (2011) menyatakan bahwa suatu perusahaan yang memiliki profit yang besar harus aktif melakukan CSR. Dikaitkan dengan teori agency semakin tinggi tingkat profitablitas suatu perusahaan maka semakin luas pengungkapan corporate social responsibility, perolehan laba yang semakin besar akan membuat perusahaan mengungkapkan informasi sosial yang lebih luas. Hal ini sejalan dengan penelitian terdahulu yang dilakukan Nurkhin (2010), Putra dkk (2011) dan Sari (2012) yang menyatakan bahwa terdapat pengaruh profitabilitas dengan pengungkapan corporate social responsibility (CSR). Berdasarka uraian diatas, maka hipotesis dalam penelitian ini merumuskan sebagai berikut:
H1:Profitabilitas

berpengaruh signifikan terhadap pengungkapan Corporate Social Responsibility (CSR)

\section{Pengaruh Leverage terhadap Pengungkapan Corporate Social Responsibility (CSR)}

Perusahaan dalam menjalankan aktivitasnya membutuhkan dana atau modal untuk mendanai usahanya, perusahaan memiliki beberapa sumber dana. Dana selalu dibutuhkan untuk menutupi seluruh atau sebagian dari biaya yang diperlukan, baik dana jangka pendek maupun jangka panjang. Dalam memenuhi kebutuhan dananya, perusahaan menggunakan modal sendiri dan juga pinjaman atau hutang. Di kaitkan dengan teori agensi merupakan hubungan keagenan antara manajer dengan pemilik utang, kemampuan dalam meningkatkan hutang penting dalam perusahaan. Perusahaan dengan tinggkat leverage yang tinggi cenderung akan mengurangi pengungkapan tanggung jawab sosial yang dibuatnya agar tidak menjadi sorotan dari para debtholder (Nur dan Priantinah, 2012).

Hal ini sejalan dengan penelitian yang dilakukan Putra dkk (2011), Nur dan Priantinah (2012) yang menyatakan bahwa terdapat pengaruh leverage terhadap pengungkapan corporate social responsibility (CSR). Berdasarkan uraian diatas, maka hipotesis dalam penelitian ini merumuskan sebagai berikut:

H2:Leverage berpengaruh signifikan terhadap Pengungkapan Corporate Social Responsibility (CSR) 


\section{Pengaruh Ukuran Perusahaan terhadap Pengungkapan Corporate Social Responsibility (CSR)}

Keluasan praktik CSR bervariasi tergantung ukuran perusahaan. Organisasi yang lebih besar cenderung menunjukkan kegiatan CSR lebih banyak daripada organisasi yang lebih kecil seperti studi yang dilakukan oleh Cohen et al (1987), Haniffa dan Cooke (2005) dalam Mardikanto (2014, hlm.204). Teori legitimasi memiliki alasan tentang hubungan ukuran dan pegungkapan, perusahaan yang lebih besar melakukan aktivitas yang lebih banyak sehingga memiliki pengaruh yang lebih besar terhadap masyarakat, memiliki pemegang saham yang punya perhatian terhadap program sosial yang dilakukan perusahaan dan laporan tahunan merupakan alat yang efisien untuk mengkomunikasikan informasi (Nur, 2012).

Hal ini dikarenakan organisasi yang lebih besar menghadapi tekanan yang lebih besar dari masyarakat untuk bisa berperilaku sosial yang bertanggung jawab. Dapat disimpulkan bahwa organisasi yang lebih besar biasanya melakukan lebih banyak kegiatan CSR dalam rangka untuk tetap bertanggung jawab secara berkelanjutan.

Hal ini sejalan dengan penelitian yang dilakukan Sembiring (2006), Sari (2012), Nur dan Priantinah (2012) yang menyatakan bahwa ukuran perusahaan terdapat pengaruh terhadap pengungkapan corporate social responsibility (CSR).

H3:Ukuran Perusahaan berpengaruh signifikan terhadap

Pengungkapan Corporate Social Responsibility (CSR)
Metode Penelitian

Populasi dan Teknik Pengambilan sample

Populasi adalah wilayah generalisasi yang terdiri atas objek/subjek yang mempunyai kualitas dan karakteristik tertentu yang ditetapkan oleh peneliti untuk dipelajari dan kemudian ditarik kesimpulannya (Sugiyono, 2010, hlm.117). Populasi yang akan mejadi objek penelitian ini adalah perusahaan sektor pertambangan yang terdaftar Bursa Efek Indonesia (BEI) yang menerbitkan laporan keuangan tahunan perusahaan pada periode 2011-2013.

Sampel adalah bagian dari jumlah dan karakteristik yang dimiliki oleh populasi tersebut (Sugiyono, 2010, hlm.118). Teknik yang digunakan dalam penentuan sampel pada penelitian ini adalah Purposive sampling yaitu yang memenuhi kriteria tertentu. Berikut ini adalah kriteria pemilihan sample dalam penelitian ini, antara lain:

a. Perusahaan sektor pertambangan yang telah go public atau terdaftar di Bursa Efek Indonesia (BEI) selama periode 2011-2013.

b. Perusahaan sektor pertambangan yang tidak mengalami delisting selama tahun penelitian.

c. Perusahaanyang mempublikasikan laba bersih secara terus menerus selama periode 2011-2013.

d. Perusahaan yang mempublikasikan laporan keuangan tahunan yang lengkap (mengungkapkan CSR) dan laporan keberlanjutan selama periode tahun 2011-2013. 


\section{Definisi Opersional Variabel}

Variabel dependen

Pegungkapan corporate social responsibility adalah proses pengkomunikasian dampak sosial dan lingkungan dari kegiatan ekonomi organisasi terhadap kelompok khusus yang berkepentingan dan terhadap masyarakat secara keseluruhan. (Sembiring, 2005).

Kategori pengungkapan diberi skor 1 dimana jika perusahaan mengungkapkan 1 item corporate social responsibility dan jika perusahaan tidak megungkapkan diberi skor 0 .

\section{Variabel independent}

$$
C S R I j=\frac{\sum X i j}{n j}
$$

\section{Profitabilitas}

Profitabilitas

merupakan

kemampuan perusahaan dalam menghasilkan laba atau tingkat keuntungan dengan menggunakan sumber-sumber yang dimiliki perusahaan (Sudanan, 2011). Profitabilitas dalam penelitian ini diukur dengan return on asset (ROA) sebagai berikut :

\section{Leverage}

$$
R O A=\frac{\text { Earning After Tax }}{\text { Total Asset }}
$$

Leverage merupakan rasio yang digunakan untuk mengukur sejauh mana aktiva perusahaan dibiayai dengan utang (Kasmir 2013). Leverage yang digunakan dalam penelitian ini diukur menggunakan debt to equity ratio (DER) sebagai berikut :

\section{Ukuran Perusahaan}

Ukuran perusahaan merupakan skala yang digunakan dalam menentukan besar kecilnya suatu perusahaan (Sari, 2012). Ukuran perusahaan yang digunakan dalam penelitian ini diukur dengan logaritma total asset sebagai berikut :

$$
\text { Size }=\text { Ln Total Asset }
$$

\section{Teknik Analisis Data}

Teknik analisi data digunakan dalam melakukan pengujian hipotesis dalam penelitian ini adalah analisis regresi linear berganda. Berikut adalah model regresi berganda yang digunakan untuk menguji hipotesis dalam penelitian ini adalah:

\begin{tabular}{|c|c|}
\hline Y & $=$ Indeks Pengungkapan \\
\hline A & $=$ Konstanta \\
\hline$\beta 1, \beta 2, \beta 3$ & $=$ Koefisien regresi \\
\hline $\mathrm{X} 1$ & $=$ Profitabilitas \\
\hline $\mathrm{X} 2$ & $=$ Leverage \\
\hline $\mathrm{X} 3$ & $=$ Ukuran Perusahaan \\
\hline A & $=$ Konstanta \\
\hline E & $=$ error \\
\hline
\end{tabular}

$$
\mathrm{Y}=\alpha+\beta 1 \mathrm{X} 1+\beta 2 \mathrm{X} 2+\beta 3 \mathrm{X} 3+\mathrm{e}
$$

Keterangan :

\section{Hasil dan Pembahasan Uji F}

Uji F bertujuan untuk mengetahui adanya pengaruh secara bersama-sama antara variabel-variabel independen (profitabilitas, leverage, dan ukuran perusahaan) terhadap variabel dependen (pengungkapan corporate social responsibility). Uji $\mathrm{F}$ dilakukan dengan melihat nilai signifikansinya.

$$
D E R=\frac{\text { Total Debt }}{\text { Equity }}
$$


Tabel 14 Hasil Uji F ANOVA $^{\mathrm{a}}$

\begin{tabular}{llll}
\hline Model & F & Sig. \\
\hline & Regression & 3.904 & $.018^{\mathrm{b}}$ \\
1 & Residual & & \\
& Total & & \\
\hline
\end{tabular}

a. Dependent Variable: CSR

b. Predictors: (Constant), Ukuran Perusahaan, Profitabilitas, Leverage

Berdasarkan hasil dari tabel 14 dapat disimpulkan bahwa nilai $F_{\text {hitung }}$ sebesar 3,904, sedangkan $F_{\text {tabel }}$ dapat $\mathrm{df}$ $=$ jumlah sampel $(\mathrm{N})-\mathrm{k}-1=(34-3-$ $1)$, maka $\mathrm{df}=30$. Dengan menggunakan table distribusi $\mathrm{F}$ dan taraf signifikan 0,05 diporoleh nilai $\mathrm{F}_{\text {tabel }} 2,88$, maka $F_{\text {hitung }} 3,904>F_{\text {tabel }}$ 2,88. Dengan signifikansi dalam penelitian ini sebesar $0,018<0,05$ dengan demikian dapat disimpulkan bahwa profitabilitas, leverage dan ukuran perusahaan secara simultan berpengaruh signifikan terhadap pengungkapan Corporate Social Responsibility.

\section{Uji Determinasi (Adjusted $\mathbf{R}^{2)}$}

Koefisien determinasi (Adjusted $\mathrm{R}^{2}$ ) digunakan untuk mengukur seberapa jauh kemampuan model dalam menerangkan variasi variabel dependen.

\begin{tabular}{|c|c|c|c|}
\hline \multicolumn{4}{|c|}{$\begin{array}{c}\text { Tabel } 15 \text { Uji Adjusted } \mathbf{R}^{2} \\
\text { Model Summary } \\
\end{array}$} \\
\hline Model & $\mathrm{R}$ & R Square & $\begin{array}{c}\text { Adjusted R } \\
\text { Square }\end{array}$ \\
\hline 1 & $.530^{\mathrm{a}}$ & .281 & .209 \\
\hline
\end{tabular}

a. Predictors: (Constant), Ukuran Perusahaan, Profitabilitas, Leverage

b. Dependent Variable: CSR

Berdasarkan table 15 dapat diketahui bahwa nilai Adjusted $R$ Square sebesar 0,209 atau 20,9\%. variabel independen (profitabilitas, leverage, dan ukuran perusahaan) yang digunakan dalam penelitian ini mampu menjelaskan sebesar 20,9\% variabel dependen (Pengungkapan corporate social responsibility). Sedangkan sisanya sebesar 79,1\% dipengaruhi atau dijelaskan oleh variabel lain yang tidak dimasukan dalam penelitian ini.

\section{Uji T (Parsial)}

Uji t digunakan untuk mengetahui pengaruh masing-masing variabel independen terhadap variabel dependen. Pengujian dilakukan dengan membandingkan $t_{\text {tabel }}$ dengan $t_{\text {hitung. }} T_{\text {tabel }}$ dilihat pada tabel statistik pada sigifikansi 0,05 . Berikut ini adalah tabel yang menjelaskan mengenai hasil uji parsial.

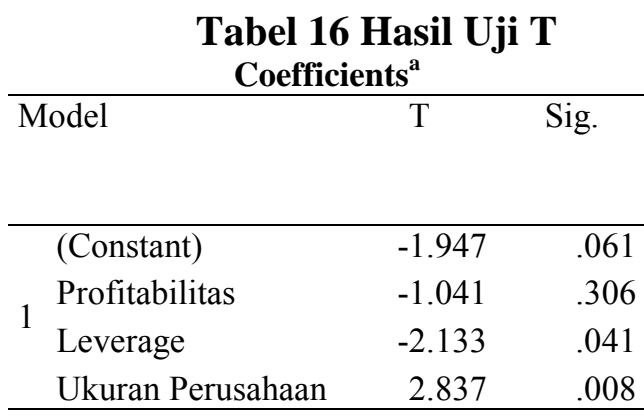

a. Dependent Variable: CSR

Berdasarkan hasil dari tabel 16, profitabilitas memiliki $t_{\text {hitung }}$ sebesar 1,041 sedangkan $t_{\text {tabel }}$ sebesar 2,04227, maka $t_{\text {hitung }}<t_{\text {tabel }}$ dengan signifikan sebesar 0,306 $>0,05$ dengan demikian $\mathrm{Ho}_{1}$ diterima dan $\mathrm{Ha}_{1}$ ditolak, sehingga dapat disimpulkan profitabilitas tidak berpengaruh signifikan terhadap pengungkapan corporate social responsibility.

Berdasarkan hasil dari table 16, leverage memiliki $t_{\text {hitung }}$ sebesar 2,133 sedangkan $t_{\text {tabel }}$ sebesar 2,04227, maka $t_{\text {hitung }}>t_{\text {tabel }}$ dengan signifikan sebesar 
$0,041<0,05$ dengan demikian $\mathrm{Ho}_{2}$ ditolak dan $\mathrm{Ha}_{2}$ diterima, sehingga dapat disimpulkan leverage berpengaruh signifikan terhadap pengungkapan corporate social responsibility.

Berdasarkan hasil dari tabel 16, ukuran perusahaan memiliki $t_{\text {hitung }}$ sebesar 2,837 sedangkan $t_{\text {tabel }}$ sebesar 2,04227, maka $t_{\text {hitung }}>t_{\text {tabel }}$ dengan signifikan sebesar $0,008<0,05$ dengan demikian $\mathrm{Ho}_{3}$ ditolak dan $\mathrm{Ha}_{3}$ diterima, sehingga dapat disimipulkan bahwa ukuran perusahaan berpengaruh signifikan terhadap pengungkapan corporate social responsibility.

\section{Analisis Regresi Berganda}

Hasil analisis regresi adalah berupa koefisien untuk masing-masing variabel bebas. Koefisien ini diperoleh dengan cara memprediksi nilai variabel terikat dengan suatu persamaan. Berdasarkan hasil olah data dalam penelitian ini diperoleh hasil sebagai berikut:

\begin{tabular}{|c|c|c|c|}
\hline & Berga & $\begin{array}{l}\text { UJi } \\
\text { nda } \\
\text { ents }^{\text {a }}\end{array}$ & \\
\hline \multirow[t]{2}{*}{ Model } & \multicolumn{2}{|c|}{$\begin{array}{l}\text { Unstandardized } \\
\text { Coefficients }\end{array}$} & $\begin{array}{l}\text { Standardized } \\
\text { Coefficients }\end{array}$ \\
\hline & B & $\begin{array}{l}\text { Std. } \\
\text { Error }\end{array}$ & Beta \\
\hline (Constant) & -1.692 & .869 & \\
\hline Profitabilitas & -.717 & .688 & -.225 \\
\hline 1 Leverage & -.228 & .107 & -.462 \\
\hline $\begin{array}{l}\text { Ukuran } \\
\text { Perusahaan }\end{array}$ & .082 & .029 & .448 \\
\hline
\end{tabular}

a. Dependent Variable: CSR
Hasil dari tabel maka dapat diperoleh persamaan regresi berganda sebagai berikut:

$$
\begin{gathered}
\text { CSR }=-~-~ 1,692-0,717 \text { PROF }-0,228 \\
\text { LEV + 0,082 SIZE }
\end{gathered}
$$

Keterangan:

CSR = Pengungkapan

Corporate Social Responsibility

PROF $=$ Profitabilitas

$\mathrm{LEV} \quad=$ Leverage

SIZE $=$ Ukuran Perusahaan

Variabel profitabilitas memiliki koefisien regresi sebesar - 0,717 menyatakan bahwa setiap kenaikan 1 satuan profitabilitas maka akan menurunkan pengungkapan corporate social responsibility sebesar 0,717 . Terdapat hubungan negatif antara profitabilitas dengan pengungkapan corporate social responsibility, dimana semakin besar profitabilitas maka akan menurunkan pengungkapan corporate social responsibility.

Variabel leverage memiliki koefisien regresi sebesar - 0,228 menyatakan bahwa setiap kenaikan 1 satuan leverage maka akan menurunkan pengungkapan corporate social responsibility sebesar 0,228.

Variabel ukuran perusahaan memiliki koefisien regresi sebesar 0,082 menyatakan bahwa setiap kenaikan 1 satuan ukuran perusahaan maka akan meningkatkan pengunkapan corporate social responsibility 0,082. Koefisien positif berarti terjadi hubungan positif antara ukuran perusahaan dengan pengungkapan corporate social responsibility, dimana semakin besar ukuran perusahaan maka akan 
meningkatkan pengungkapan corporate social responsibility.

\section{Pembahasan}

Setelah melakukan analisis data dan pengujian hipotesis pengaruh profitabilitas, leverage, dan ukuran perusahaan terhadap pengungkapan corporate social responsibility pada 12 perusahaan disektor pertambangan yang terdaftar di Bursa Efek Indonesia (BEI) selama periode tahun 2011 sampai dengan 2013.

Dari hasil analisis berdasarkan tabel 14 atau uji $F$ secara simultan (bersama-sama), ditemukan bahwa variabel-variabel independen (profitabilitas, leverage, dan ukuran perusahaan) secara bersama-sama berpengaruh signifikan terhadap variabel dependen (pengungkapan corporate social responsibility), artinya secara simultan variabel profitabilitas, leverage, dan ukuran perusahaan sebagai variabel yang dapat mempengaruhi pengungkapan corporate social responsibility.

Hasil uji hipotesis secara parsial menunjukkan bahwa variable profitabilitas

yang diproksi dengan ROA menunjukkan tidak berpengaruh signifikan terhadap pengungkapan corporate social responsibility. Maka $\mathrm{H}_{01}$ diterima sedangkan $\mathrm{H}_{\mathrm{a} 1}$ ditolak. Penelitian ini tidak mendukung hasil penelitian sebelumnya yang telah dilakukan oleh Nurkhin (2010), Putra dkk (2011) dan Sari (2012). Hasil penelitian ini sejalan dengan hasil penelitian sebelumnya yang dilakukan oleh Sembiring (2005) dan Nur \& Priantinah (2012) yang menemukan pengaruh profitabiltas yang tidak signifikan terhadap corporate social responsibility. Hasil penelitian menolak teori agensi yang dimana bahwa perolehan laba yang semakin besar akan membuat perusahaan mengungkapkan corporate social responsibility secara luas. Hasil penelitian ini dapat dilihat tingkat profitabilitas pada tahun 2011-2013 pada PT. Harum Energy Tbk sebesar 0,3949, 0,3001, dan 0,1031, sedangkan pengungkapan corporate social responsibility sebesar 0,2278 , 0,2405, dan 0,3164. Dapat disimpulkan bahwa perusahaan mengalami penurunan profitabilitasnya setiap tahunnya, akan tetapi pada pengungkapan corporate social responsibility terus meningkat atau pengunkapannya semakin luas. Hal ini didukung dengan argumentasi bahwa ketika perusahaan memiliki tingkat laba yang tinggi, perusahaan (manajemen) menganggap tidak perlu melaporkan hal-hal yang dapat menggangu informasi tentang sukses keuangan perusahaan. Sebaliknya, pada saat tingkat profitabilitas rendah, mereka berharap para pengguna laporan akan membaca "good news" kinerja perusahaan. Hal ini merupakan salah satu strategi perusahaan untuk dimasa yang akan datang. "Good news" ini dapat berupa pengungkapan corporate social responsibility.

Hasil uji hipotesis secara parsial menunjukkan bahwa variable leverage yang diukur dengan DER (Debt Equity Ratio) menunjukkan berpengaruh signifikan terhadap pengungkapan corporate social responsibility. Maka $\mathrm{H}_{02}$ ditolak sedangkan $\mathrm{H}_{\mathrm{a} 2}$ diterima, sehingga hipotesis ke-2 berhasil didukung. Hasil penelitian ini sejalan 
dengan penelitian sebelumnya yang telah dilakukan oleh Putra et al (2011) dan Nur \& Priantinah (2012), yang menemukan bahwa leverage mempunyai pengaruh yang signifikan terhadap pengungkapan corporate social responsibility. Penelitian ini didukung dengan teori agensi yang menyatakan bahwa, tinggkat leverage mempunyai pengaruh terhadap pengungkapan corporate social responsibility. Manajemen perusahaan dengan tinggkat leverage yang tinggi cenderung mengurangi pengungkapan corporate social responsibility agar tidak menjadi sorotan dari para debtholders.

Hasil uji hipotesis secara parsial menunjukkan bahwa variable ukuran perusahaan yang diukur dengan Ln total aset menunjukkan berpengaruh signifikan terhadap pengungkapan corporate social responsibility. Maka $\mathrm{H}_{03}$ ditolak sedangkan $\mathrm{H}_{\mathrm{a}}$ diterima. Dapat disimpulkan bahwa variable ukuran perusahaan berpengaruh signifikan terhadap pengungkapan corporate social responsibility, sehingga hipotesis ke-3 berhasil didukung. Semakin besar aset yang dimiliki perusahaan maka semakin luas pengungkapan corporate social responsibility. Hasil penelitian ini sejalan dengan penelitian yang dilakukan Sembiring (2005) dan Nur dan Priantinah (2012). Menurut Cowen et al (1987) dalam Sembiring (2005), secara teoritis perusahaan besar tidak akan lepas dari tekanan. Perusahaan yang lebih besar dengan aktivitas operasi dan pengaruh yang lebih besar terhadap masyarakat mungkin akan memiliki pemegang saham yang memperhatikan program sosial yang dibuat perusahaan sehingga pengungkapan corporate social responsibility semakin luas.

\section{Keterbatasan}

Dalam penelitian ini terdapat keterbatasn yang mempengaruhi penelitian ini, diantaranya:

a. Tidak semua perusahaan di sektor pertambangan yang terdaftar di Bursa Efek Indonesia (BEI) melakukan pengungkapan Corporate Social Responsibility (CSR) baik di laporan keuangan (annual report) maupun di laporan keberlanjutan (sustainability report).

b. Terdapat unsur subjektifitas pada penilaian indeks CSR. Hal ini dikarenakan tidak adanya ketetuan baku yang dapat dijadikan standar atau acuan, sehingga penentuan indeks untuk indikator yang sama bisa berbeda untuk setiap peneliti.

\section{Kesimpulan}

Penelitian ini dilakukan untuk menguji faktor-faktor yang dapat mempengaruhi pengungkapan corporate social responsibility $\mathrm{di}$ antaranya profitabilitas, leverage, dan ukura perusahaan.. Setelah melakukan analisis data dan pengujian hipotesis pengaruh profitabilitas, leverage, dan ukuran perusahaan terhadap pengungkapan corporate social responsibility pada 12 perusahaan di sektor pertambangan yang terdaftar di Bursa Efek Indonesia (BEI) selama periode 2011-2013 dapat disimpulkan sebagai berikut: 
a. Pengujian secara simultan menunjukkan bahwa variabel independen Profitabilitas, Leverage, dan Ukuran Perusahaan memiliki pengaruh yang signifikan terhadap variabel dependen yaitu Pengungkapan Corporate Social Responsibility.

b. Pengujian secara parsial menunjukan bahwa:

1) Profitabilitas tidak mempunyai pengaruh yang signifikan terhadap pengungkapan corporate social responsibility. Hasil pengujian menolak hipotesis yang menyatakan bahwa profitabilitas berpengaruh signifikan terhadap pengungkapan corporate social responsibility.

2) Leverage mempunyai pengaruh yang signifikan terhadap pengungkapan corporate social responsibility. Hasil pengujian menolak hipotesis yang menyatakan bahwa leverage berpengaruh signifikan terhadap pengungkapan corporate social responsibility.

3) Ukuran Perusahaan berpengaruh signifikan terhadap pengungkapan corporate social responsibility. Hasil pengujian menerima hipotesis yang menyatakan bahwa ukuran perusahaan berpengaruh terhadap signifikan pengungkapan corporate social

responsibility.

c. Hasil pengujian koefisien determinasi (adjusted $\mathrm{R}^{2}$ ) menunjukan bahwa presentase pengaruh variabel independen (profitabilitas, leverage, dan ukuran perusahaan) terhadap variabel dependen yaitu pengungkapan corporate social responsibility sebesar 20,9\% atau variasi variabel independen yang digunakan dalam penelitian ini mampu menjelaskan sebesar $30,5 \%$ variabel dependen. Sedangkan sisanya sebesar $\quad 79,1 \%$ dipengaruhi atau dijelaskan oleh variabel lain yang tidak dimaukan dalam penelitian ini.

\section{Saran}

Berdasarkan hasil analisis dan kesimpulan yag telah di uraikan maka saran yang dapat diberikan adalah sebagai berikut:

1. Bagi peneliti selanjutnya, sebaiknya memperbanyak jumlah sampel yang akan di teliti dengan menggunakan periode waktu yang lebih panjang dari penelitian ini dan sektor perusahaan yang berbeda dengan penelitian ini agar hasil penelitian selanjutnya lebih tepat dan akurat.

2. Bagi Perusahaan, Lebih tingkatkan kembali dalam mempertimbangkan kepedulian perusahaan terhadap lingkungan sekitar tidak pada pengungkapannya saja, tetapi juga pelaksanaannya dalam hal 
pertanggung jawaban sosial perusahaan.

3. Bagi Investor diharapkan dapat menjadi bahan pertimbangan bagi investor dalam menanamkan sahamnya diperusahaan besar, yang dianggap paling menguntungkan baik jangka panjang maupun jangka pendek.

\section{Daftar Pustaka}

Indonesia_Undang-Undang No. 40 Tahun 2007 tentang Perseroan Terbatas.

Badjuri, A 2011, 'Faktor-faktor fundamental, mekanisme, pengungkapanCorporate Social Responsibility (CSR) perusahaan manufaktur dan sumberdaya alam di Indonesia Corporate governance mechanism, fundamental factors, Corporate Social Responsibility (CSR) disclosure of a natural resource and manufactur company in Indonesia',Dinamika Keuangan dan Perbankan,vol.3, no.1,Mei 2011. hlm.38 - 54, ISSN.19794878.

Bursa Efek Indonesia, Laporan keuangan tahunan, Diakses 30 April 2015 , http://www.idx.co.id/idid/berand a/perusahaantercatat/laporankeu angandantahunan.aspx

Hadi, N 2014, 'Corporate social responsibility', Graha Ilmu, Yogyakarta.

Harahap, SS 2011, 'Analisis kritis atas laporan keuangan', PT Raja Grafindo Persada, Jakarta.
Harahap, SS 2012, 'Teori akuntansi', PT Raja Grafindo Persada, Jakarta.

Kasmir, 2013, 'Analisis laporan keuangan', PT Raja Grafindo Persada, Jakarta.

Sudana, IM 2011, 'Manajemen keuangan perusahaan teori \& praktik', Erlangga.

Nur, M \& Priantinah, D 2012, 'Analisis faktor-faktor yang mempengaruhi pengungkapan corporate social responsibility di Indonesia', Jurnal Nominal, vol.1, no.1, hlm.22-34

Nurkhin, A 2010, 'Corporate governance dan profitabilitas, pengaruh terhadap pengungkapan corporate social responsibility sosial perusahaan', Jurnal Dinamika Akuntansi, vol.2, no.1, hlm.4655 ,

Purwanto, A 2011, 'Pengaruh tipe industry, ukuran perusahaan, profitabilitas terhadap corporate social responsibility', Jurnal Akuntansi \& Auditing, vol.8, no.1, hlm.1-94.

Putra dkk 2010, 'Pengaruh size, profitabilitas, leverage, kepemilikan dalam negeri dan kepemilikan asing terhadap pengungkapan tanggung jawab sosial perusahaan', Jurnal Penelitian Universitas Jambi Seri Humaniora, vol.3, no.2, hlm.37-48.

Sari, RA 2012,'Pengaruh karakteristik perusahaan terhadap corporate social responsibility disclosure pada perusahaan manufaktur yang terdaftar di Bursa Efek 
Indonesia', Jurnal Nominal, vol.1,no.1, hlm.124-140.

Sembiring, ER 2005, 'Karakteristik perusahaan dan pengungkapan tanggung jawab social: study empiris pada perusahaan yang tercatat di Bursa Efek Jakarta', Simpsium Nasional Akuntansi VII solo, 15-16 September 2005, hlm.379-395.

Sugiyono 2010, 'Metode penelitian pendidikan (pendekatan kuantitatif, kualitatif, dan $R \& D)$ ', Alfabeta, Bandung.

Universitas Pembangunan Nasional

"Veteran" Jakarta 2014, pedoman penulisan karya ilmiah bagi dosen dan mahasiswa, Lembaga Penelitian dan Pemberdayaan Masyarakat, Jakarta. 